\title{
BRUSSELS AND KLAIPEDA: THE DOMESTIC IMPACT OF EU MARITIME LAW
}

\author{
Stefan Kirchner ${ }^{1}$ \\ DOI: https://doi.org/10.7220/2029-4239.18.5
}

\section{SUMMARY}

Both directly and indirectly, EU law impacts domestic legal systems. This also applies to maritime affairs. Even though Lithuania's political and economic focus is oriented more towards the major cities, Vilnius and Kaunas, maritime issues, ranging from fishing to transport, tourism to energy, are (or have the potential to become) important aspects of Lithuania's economic and political life. In this text it will be shown how the work of the EU can influence domestic maritime law. This will be done by looking at the interaction of the EU and member states with global international treaties. Among the many types of international treaties concerning maritime affairs, liability conventions are often overlooked by academia but are of significant importance for businesses operating in the maritime sector as well as for the safety of those who interact with maritime actors, such as coastal populations or passengers on cruise vessels or ferries. Using the example of the EU's implementation of the Athens Convention, which regulates the liability for damages suffered by passengers on ships, this text aims at showing some of the potentials, but also complications, which can be created by the EU's entry into a legal field which had already been regulated through international treaties for decades before the creation of the EU.

\footnotetext{
${ }^{1}$ Rechtsanwalt Dosentti Dr. Stefan Kirchner, MJI is University Researcher for Arctic Law and Adjunct Professor for Fundamental and Human Rights at the University of Lapland in Rovaniemi, Finland. He is admitted to the practice of law in Frankfurt am Main, Germany. Earlier he served as a lawyer for Germany's Federal Maritime and Hydrographic Agency in Hamburg, as trainee lawyer in the Law of the Sea Division of Germany's Federal Foreign Office in Berlin and as Associate Professor for the Law of the Sea at Vytautas Magnus University in Kaunas, Lithuania. He is currently co-chairing the Law of the Sea Interest Group of the American Society of International Law. This text only reflects the author's private opinion and is not attributable to any of the organisations the author is or has been associated with.
} 


\section{KEY WORDS}

Maritime, law, EU, shipping, transport.

\section{INTRODUCTION}

The European Union (EU) has a far-reaching impact on the legal and economic reality of all member states, including direct effect. ${ }^{2}$ Today, despite the continued relevance of the principle of subsidiarity, ${ }^{3}$ many important decisions are no longer made locally or nationally but in Brussels. This also affects the maritime sector. Rules which are to be taken into account by Lithuanian maritime businesses are not created in Klaipedda or Vilnius but in Brussels. Sometimes the practical impact of EU Law is well known and obvious, but often it is technical in nature and known only to experts in a specific field. Sometimes the impact of EU Law is significant but not obvious. Many EU norms will hardly ever matter to average citizens. Often, however, EU law has practical benefits for citizens. EU Maritime Law is one example for such a field. ${ }^{4}$

In this text it will be shown how EU law impacts national law in the maritime sector. In a world which is growing closer together in economic, cultural and political terms, the oceans matter for everybody. This is particularly the case for small coastal states such as Lithuania. In the long run, but also already today, Lithuania's economy and security depends on remaining connected to the world. Free interaction with other states requires commerce and navigation. Today, the sea is not only responsible for tourism income in places like Nida or Klaipeda, but also for contributing to Lithuania's energy security. ${ }^{5}$ Together with the transportation of people and goods, these are already important factors, which highlight the needs for an increasing attention to coastal and maritime issues. There is a relative distance of population centres in the country, i.e., Vilnius and Kaunas, the coast matters. Unlike in the case of e.g. the Nordic countries, Lithuanian self-perception as a maritime state is influenced by the relatively short coastline and the particular geography of the nation's coastline. Lithuania has the potential to benefit greatly from its maritime position, helping it overcome existing long-term economic obstacles caused by historic injustices during World War II and the Soviet occupation and strengthen its security in light of current challenges. Making best use of the possibilities afforded to Lithuania by its

${ }^{2}$ See European Court of Justice, NV Algemene Transport- en Expeditie Onderneming van Gend \& Loos v Netherlands Inland Revenue Administration, Reference for a preliminary ruling: Tariefcommissie Netherlands [Van Gend en Loos], Case 26/62, Judgment of 5 February 1963, http://eur-lex.europa.eu/legalcontent/EN/TXT/PDF/?uri=CELEX:61962CJ0026\&from=EN.

${ }^{3}$ Article 5 (3) Treaty on European Union.

4 The term "EU Maritime Law" as used here has a wider meaning than the term "maritime law" usually has in English-speaking countries. While "maritime law" is often understood to refer to civil or private law norms, as opposed to the law of the sea as a subset of public law, the term "EU Maritime Law" is used here in parallel to the EU's own terminology regarding maritime policy and is meant to refer to EU norms which in one way or an other refer to uses of the seas and which are created as a consequence of the EU's maritime policy.

${ }^{5}$ See e.g. James Kanter, At Anchor Off Lithuania, Its Own Energy Supply, in: New York Times, 4 July 2013, http://www.nytimes.com/2013/07/05/business/energy-environment/lithuania-aims-for-energyindependence.html. 
geographical position requires knowledge among current and potential economic actors of the legal environment applicable to maritime operations. This text aims at contributing to strengthening awareness of such maritime legal issues in Lithuania.

\section{EXAMPLES FOR EU REGULATION OF MARITIME ISSUES}

The work of the EU in regulating maritime matters covers a wide range of issues, ${ }^{6}$ from fishing to transport. In historical terms, the EU is a relative latecomer to the international law of the sea. This text is concerned not with the private law aspects of the transport by sea but rather with its public law dimensions and regulatory approaches, which can be found in domestic administrative law, the international law of the sea and EU law. A classical field of international law, the international law of the sea has long been dominated by international treaties between states. In the course of the 20th century, the International Maritime Organization (IMO) has taken on an exceedingly important role in creating new norms of international law in this field, not only reflecting but often driving the increasing importance of international organizations in international law-making.?

Rather than looking at the totality of maritime issues, which would far exceed the limits of this text, a closer look appears to be more practical for the purposes of this text. In recent years, the human dimension of maritime affairs has gained increasing interest among international lawyers as well as non-state actors, such as Human Rights at Sea or the seafarer missions of the Catholic church and other religious groups. This focus on the person also includes the human rights dimension of shipping, which covers the rights of workers in the maritime sector ${ }^{8}$ or of those living along the coasts and potentially affected by forms of vessel-borne marine pollution, such as oil spills. ${ }^{9}$ The human rights dimension of international shipping was long ignored but there have been significant steps forward in recent years. Individual rights nevertheless continue to remain somewhat of a marginal issue, both from the perspective of human rights law and from the perspective of the law of the sea. It therefore appears appropriate to showcase the role of the EU in shaping maritime law in the member states by putting the spotlight on an area which directly affects individuals. The focus of this text will therefore be on one specific issue, rather than on the totality of marine-related topics regulated by the EU, the protection of the rights of passengers on ships through EU law. By presenting this issue in a broader context, this text is meant to contribute to raising awareness of the human rights dimension of international shipping.

${ }^{6}$ See European Commission, Maritime Affairs, https://ec.europa.eu/maritimeaffairs/home_en.

${ }^{7}$ Cf. Stefan Kirchner, Effective Law-Making in Times of Global Crisis - A Role for International Organizations, in: 2 Göttingen Journal of International Law (2010), pp. 267-292, at pp. 277 et seq.

${ }^{8}$ See for example Heiko Schäffer, Neuregelungen der Lebens- und Arbeitsbedingungen in der Seeschifffahrt. Das neue IAO-Seearbeitsübereinkommen - Umsetzung ins nationale Recht, Deutscher Verkehrsgerichtstag, 47. Verkehrsgerichtstag (2009), pp. 388-395.

${ }^{9}$ See e.g. Stefan Kirchner, Coastal Communities and Oil Pollution Compensation, in: Jūrų teisè, 23 March 2016, https://juruteise.wordpress.com/2016/03/23/coastal-communities-and-oil-pollutioncompensation/. 


\section{PASSENGER RIGHTS}

\section{Context}

Passenger rights are an important concern in international travel. For air travel, passenger rights are well established and published. In the maritime sector, however, the awareness among passengers of their rights is often limited. One potential reason for the differences in perception is the way cruise ship trips are booked by passengers, i.e., primarily for tourism purposes. Passenger rights, though, go beyond recreational uses of ships for transport but are also relevant for transport of persons by ferry. This highlights the practical relevance of passenger rights and its potential long-term relevance for Lithuania, especially if the coastal tourism sector is developed further. Rather than looking at domestic Lithuanian law from the outside, this text is concerned with looking at EU law from the perspective of the member state which has to implement it. The focus will be on the realm of norms which is central to the law of the sea, international law, and the EU's approach to it.

\section{Multiple Legal Frameworks}

This already indicates that in the case at hand we are talking not only about one legal framework but about several: international law, EU law and domestic law.

Passenger rights are protected through two very similar but slightly different international legal frameworks:

The Athens Convention relating to the Carriage of Passengers and their Luggage by Sea ${ }^{10}$ (1974 Athens Convention) is an international treaty which was created in 1974 and which entered into force 1987. In 2002 a Protocol, which is distinct from an earlier protocol,${ }^{11}$ was created which essentially replaced the older Athens Convention. ${ }^{12}$ Lithuania is a party to this 2002 Protocol, which entered into force 2014. The Athens Convention, in the form it was given with the 2002 Protocol, in the following referred to as "PAL" (short for PAssenger Liability) or "the Convention", has also been ratified by the EU and by several, but not all, other EU member states.

The EU, as a party to PAL, has implemented it through the Regulation (EC) No 392/2009. ${ }^{13}$ Back in 2009 it still acted under the label EC, as this was just before the entry into force of the

10 Athens Convention relating to the Carriage of Passengers and their Luggage by Sea, http://www.jus.uio.no/english/services/library/treaties/07/7-04/carriage-passangers-luggage-seaconsolidated.xml

${ }^{11}$ Protocol to the Athens Convention relating to the Carriage of Passengers and their Luggage by Sea (PAL Protocol 1976), http://www.jus.uio.no/english/services/library/treaties/07/7-04/palprot-1976.xml.

12 For the consolidated text after the 2002 Protocol see http://folk.uio.no/erikro/WWW/corrgr/Consol.pdf.

${ }^{13}$ Regulation (EC) No 392/2009 of the European Parliament and of the Council of 23 April 2009 on the liability of carriers of passengers by sea in the event of accidents (Text with EEA relevance), Official Journal 2009 L 131, pp. 24-46, 28 May 2009, http://eur-lex.europa.eu/legal- 
Treaty of Lisbon. The regulation remains binding EU law. Back then, the EU had asked member states to ratify PAL in order to hasten its entry into force as an international treaty. Some EU member states are also parties to the Convention. For these states, including Lithuania, this means that there are now legal obligations to implement an international treaty, PAL, and Regulation (EC) No 392/2009, in the following referred to as "the Regulation", which has direct effect in the member states. Normally this would not be a problem, as Lithuania could comply with its obligations under PAL by virtue of the direct applicability of the aforementioned regulation. The problem faced by those member states which, like Lithuania, had heeded the call from Brussels to ratify PAL, is that the Regulation does not implement PAL exactly. In fact, the content of the Regulation is not identical to the content of the Convention. As a result, there are now two very similar, but not exactly identical, legal regimes concerning the liability for damages suffered by ship passengers - both of which have to be implemented by Lithuania. As EU law takes precedence over Lithuanian law (and in this case is actually directly applicable in Lithuania), Lithuania is forced by the EU to violate its international legal obligations under PAL, international obligations which the EU had asked the member states to accept in the first place. The imperfect implementation of PAL by the EU (which is a party to PAL) leads to a violation of international law by Lithuania, a violation of international law which Lithuania is unable to prevent, unless it were willing to violate EU law. The EU's failure to properly implement an international treaty which has been ratified by the EU therefore provides legal challenge for member states like Lithuania. In practice, the differences are not great, but they do exist:

The 2002 PAL, albeit formally only a protocol to the 1974 Athens Convention, is - for all practical purposes - a regular international treaty. Unlike regular protocols to international treaties, the PAL can be meaningfully ratified without having ratified the original 1974 . This is the case for Lithuania: Lithuania has ratified the 2002 protocol but never ratified the 1974 Athens Convention. Lithuania is bound by PAL, i.e., by the Athens Convention as amended in 2002, but not by the 1974 treaty, which is superseded by the 2002 protocol. Likewise it is possible for a state to have ratified the 1974 Athens Convention but not the 2002 PAL. In that case, that state's international legal obligations continue to derive from the 1974 treaty (which would lead to even more complications for EU member states).

As a liability convention, PAL can be seen, from a macro-systematic legal perspective, in the context of other liability conventions, for example for oil spills caused by oil as cargo ${ }^{14}$ or by bunker fuel. ${ }^{15} \mathrm{~A}$ liability convention is an international treaty which requires flag states to require ship owners or (like in this case, operators) to take conclude an insurance contract which covers specific minimum amounts of money to ensure that those who suffer a damage which falls into the scope of the convention are compensated adequately. Rather than directly regulating the behavior of ship owners or operators, states which are parties to such an international treaty can rely on standards set by the insurance industry. Maritime insurance schemes have long played an

content/EN/TXT/PDF/?uri=CELEX:32009R0392\&from=EN; On the issues covered by the Regulation see e.g. Grit Tüngler / Jan Martin Hoffmann / Stefan Kirchner, "Europarechtliche Unfallhaftung und Versicherungspflicht der Anbieter von Seereisenden”, in: 24 Europäische Zeitschrift für Wirtschaftsrecht (2013), pp. 332-335.

14 International Convention on Civil Liability for Oil Pollution Damage (CLC), http://www.jus.uio.no/english/services/library/treaties/06/6-07/civil-liability-oil-pollutionconsolidated.xml.

15 International Convention on Civil Liability for Bunker Oil Pollution Damage, http://www.jus.uio.no/english/services/library/treaties/06/6-07/bunkers-convention.xml. 
important role in ensuring specific behavior by ship owners or operators. The fact that many key insurance companies (often organized in the form of mutual insurance schemes) are based in London means that English law, both codified and common law, remains important for the shipping industry worldwide. The insurance industry plays an important role in upholding and enhancing safety standards in shipping and insurance companies often provide maritime operators with important information concerning safety measures, for example when it comes to the risks associated with the liquefaction ${ }^{16}$ of some dry cargoes transport on ships in bulk. ${ }^{17}$ This approach to regulation, together with directly applicable, classical, domestic and international legal norms, contributes to the fact that, despite the continued risks and loss of human lives, shipping is said to be safer than ever before, albeit still dangerous. ${ }^{18}$ This method has been continued with the liability for damages caused by wrecks. ${ }^{19}$

This mixed (state regulation and standards set by the insurance industry) approach is used also elsewhere in the shipping sector (oil spill liability etc.) because of the unwillingness of ship operators to provide compensation (e.g. restrictive clauses in cruise trip contracts). In the case at hand, PAL imposes minimum insurance requirements in the event of personal or property damage suffered by passengers. ${ }^{20}$ The ship operator concludes a contract with an insurance company. The flag state certifies that the required insurances have been obtained. Port states can control the ship's papers including this document issued by the flag state. If such a certification is missing, ships can be detained in foreign ports. This in turn means a loss of income for the owner or operator of the vessel in question. For flag states, this form of implementation is relatively simple. For owners and operators the obligation to take out insurance is something that would be done anyway as a matter of common sense. For those who are at risk of being damaged, mandatory insurance schemes provide not only compensation in case of a damage but also the knowledge that everybody concerned has an economic interest in reducing the risk that they suffer any harm.

The idea behind Regulation (EC) No 392/2009 is to transfer PAL into EU law. Annex I of Regulation (EC) No 392/2009 contains norms which are almost identical to the Athens Convention, but there are some differences. For example, unlike PAL, the Regulation imposes an advance payment obligation in case of damages (in case of death: at least 21,000 EUR). ${ }^{21}$ This

${ }^{16}$ On the problem of dry cargo liquefaction see, from a legal perspective, e.g. Stefan Kirchner, Legal Approaches to Dry Cargo Liquefaction: An Arctic Perspective on a Global Problem (forthcoming, 2018).

${ }^{17}$ For an overview see e.g. the collection published by Gard AS, Liquefaction of solid bulk cargoes (2014), http://www.gard.no/Content/20651223/Cargo\%20liquefaction\%20January\%202014.pdf.

18 Cf. Sean McCrystal, Shipping: Is the industry safer than ever? Part I, 19 January 2017, https://www.mcmurdogroup.com/2017/01/19/shipping-industry-safer-ever-part/.

19 Nairobi International Convention on the Removal of Wrecks, 2007, http://www.jus.uio.no/english/services/library/treaties/06/6-04/imo_removal_wrecks.xml.

${ }^{20}$ Article 4bis PAL.

${ }^{21}$ Article 6 Regulation (EC) No 392/2009. 
obligation has to be implemented ${ }^{22}$ by the member states by requiring that the "carrier" 23 (which does not necessarily have to be identical with the owner or the operator of the vessel) make such advance payments in case of a damage. In terms of legislative methodology, the EU took the contents of an international treaty (which itself had undergone some changes since the first version of 1974) and turned them into one part of its overall transport policy - and made some changes to the content.

The changes made by the EU has the effect that in those EU member states which are also parties to the Convention (as requested by the EU!), there are now two legal regimes, the Convention and the Regulation. Under EU law, the Regulation is directly applicable. Due to the differences between the Regulation and the Convention, states which are also parties to the Convention are at risk of violating international law (i.e., PAL) by implementing EU law (the Regulation). From the perspective of EU law, the Regulation takes precedence over PAL. In the legal relationship between a state which, like Lithuania, is a member of the European Union and has ratified PAL on one hand, and every non-EU member state which has ratified PAL, this means that the EU member state is in violation of the international legal obligations accepted when ratifying PAL. While this result is unsatisfactory from a legal perspective, it has been caused by good intentions on the part of the EU concerning the strengthening of the rights of passengers.

\section{CONCLUSIONS}

The law of the sea is primarily regulated through international law. In recent decades, the EU has emerged as a significant actor in this field. Even though the EU is becoming more important as a legal actor, it is not a party to many relevant treaties. In case treaties have been ratified by both the EU and (some) member states, there is a risk of differing interpretations or applications, as has been shown in this text. On the other hand does the involvement of the EU signal an increasing interest in maritime matters, which strengthens this field of law in general.

For the time being, the law of the sea is still very much classical, state-based, international law. Neither the 1982 Law of the Sea Convention nor many other treaties in the field are fully ready for a supranational entity such as the EU; nor is the EU enough of a 'state' yet to be able to replace the member states as actors in international maritime law, especially shipping law. The far-reaching regulation of fisheries, in which the EU plays a major role, cannot be seen pars pro toto regarding the entire law of the sea, it is the exception rather than the norm when looking at the role of the EU. At this time, the direction of the development remains open. As was shown here, states might often have to navigate between differing legal obligations. In the long run, EU

\footnotetext{
${ }^{22}$ On the implementation of the regulation in Germany see Jan Martin Hoffmann / Grit Tüngler / Stefan Kirchner, "Das neue Seeversicherungsnachweisgesetz und die neue Seeversicherungsnachweisverordnung", in: 1 Recht der Transportwirtschaft (2013), pp. 264-267; J. M. Hoffmann / G. Tüngler / S. Kirchner, "Neuere Entwicklungen im Seeversicherungsnachweisrecht: Die neue Seeversicherungsnachweisverordnung", in: 1 Recht der Transportwirtschaft (2013) pp. 420-423; on the role of the EU in implementing the passenger liability norms found in PAL see Stefan Kirchner / Grit Tüngler / Jan Martin Hoffmann, "Carrier Liability for Damages incurred by Ship Passengers: The European Union as a Trailblazer towards a Global Liability Regime?", in: 23 University of Miami International and Comparative Law Review (2015), pp. 193-214.

${ }^{23}$ Article 6 Regulation (EC) No 392/2009.
} 
involvement can strengthen the law of the sea. For now, states cannot 'outsource' the legal treatment of maritime concerns to Brussels.

\section{LEGAL REFERENCES}

\section{Legislation}

1. Article 4bis PAL.

2. Article 6 Regulation (EC) No 392/2009

3. International Convention on Civil Liability for Bunker Oil Pollution Damage, http://www.jus.uio.no/english/services/library/treaties/06/6-07/bunkersconvention.xml

4. International Convention on Civil Liability for Oil Pollution Damage (CLC), http://www.jus.uio.no/english/services/library/treaties/06/6-07/civil-liability-oilpollution-consolidated.xml

5. Nairobi International Convention on the Removal of Wrecks, 2007, http://www.jus.uio.no/english/services/library/treaties/06/6-

04/imo_removal_wrecks.xml

\section{Other references}

6. Article 5 (3) Treaty on European Union.

7. Athens Convention relating to the Carriage of Passengers and their Luggage by Sea, http://www.jus.uio.no/english/services/library/treaties/07/7-04/carriagepassangers-luggage-sea-consolidated.xml.

8. Cf. Sean McCrystal, Shipping: Is the industry safer than ever? Part I, 19 January 2017, https://www.mcmurdogroup.com/2017/01/19/shipping-industry-safer-everpart/

9. Cf. Stefan Kirchner, Effective Law-Making in Times of Global Crisis - A Role for International Organizations, in: 2 Göttingen Journal of International Law (2010), pp. 267-292, at pp. 277 et seq.

10. For an overview see e.g. the collection published by Gard AS, Liquefaction of solid bulk cargoes (2014), http://www.gard.no/Content/20651223/Cargo\%20liquefaction\%20January\%2020 14.pdf.

11. For the consolidated text after the 2002 Protocol see http://folk.uio.no/erikro/WWW/corrgr/Consol.pdf

12. On the implementation of the regulation in Germany see Jan Martin Hoffmann / Grit Tüngler / Stefan Kirchner, "Das neue Seeversicherungsnachweisgesetz und die neue Seeversicherungsnachweisverordnung", in: 1 Recht der Transportwirtschaft (2013), pp. 264-267; J. M. Hoffmann / G. Tüngler / S. 
Kirchner, "Neuere Entwicklungen im Seeversicherungsnachweisrecht: Die neue Seeversicherungsnachweisverordnung", in: 1 Recht der Transportwirtschaft (2013) pp. 420-423; on the role of the EU in implementing the passenger liability norms found in PAL see Stefan Kirchner / Grit Tüngler / Jan Martin Hoffmann, "Carrier Liability for Damages incurred by Ship Passengers: The European Union as a Trailblazer towards a Global Liability Regime?", in: 23 University of Miami International and Comparative Law Review (2015), pp. 193-214.

13. On the problem of dry cargo liquefaction see, from a legal perspective, e.g. Stefan Kirchner, Legal Approaches to Dry Cargo Liquefaction: An Arctic Perspective on a Global Problem (forthcoming, 2018).

14. Protocol to the Athens Convention relating to the Carriage of Passengers and their Luggage by Sea (PAL Protocol 1976), http://www.jus.uio.no/english/services/library/treaties/07/7-04/palprot-1976.xml.

15. Regulation (EC) No 392/2009 of the European Parliament and of the Council of 23 April 2009 on the liability of carriers of passengers by sea in the event of accidents (Text with EEA relevance), Official Journal 2009 L 131, pp. 24-46, 28 May 2009, http://eur-lex.europa.eu/legalcontent/EN/TXT/PDF/?uri=CELEX:32009R0392\&from=EN; On the issues covered by the Regulation see e.g. Grit Tüngler / Jan Martin Hoffmann / Stefan Kirchner, "Europarechtliche Unfallhaftung und Versicherungspflicht der Anbieter von Seereisenden", in: 24 Europäische Zeitschrift für Wirtschaftsrecht (2013), pp. 332-335.

16. See e.g. James Kanter, At Anchor Off Lithuania, Its Own Energy Supply, in: New York Times, 4 July 2013, http://www.nytimes.com/2013/07/05/business/energyenvironment/lithuania-aims-for-energy-independence.html

17. See e.g. Stefan Kirchner, Coastal Communities and Oil Pollution Compensation, in: Jürų teisé, 23 March 2016, https://juruteise.wordpress.com/2016/03/23/coastalcommunities-and-oil-pollution-compensation/

18. See European Commission, Maritime Affairs, https://ec.europa.eu/maritimeaffairs/home_en.

19. See European Court of Justice, NV Algemene Transport- en Expeditie Onderneming van Gend \& Loos v Netherlands Inland Revenue Administration, Reference for a preliminary ruling: Tariefcommissie - Netherlands [Van Gend en Loos], Case 26/62, Judgment of 5 February 1963, http://eur-lex.europa.eu/legalcontent/EN/TXT/PDF/?uri=CELEX:61962CJ0026\&from=EN.

20. See for example Heiko Schäffer, Neuregelungen der Lebens- und Arbeitsbedingungen in der Seeschifffahrt. Das neue IAOSeearbeitsübereinkommen - Umsetzung ins nationale Recht, Deutscher Verkehrsgerichtstag, 47. Verkehrsgerichtstag (2009), pp. 388-395. 


\title{
SANTRAUKA
}

\section{BRIUSELIS IR KLAIPEDDA: ES POVEIKIS NACIONALINEI JŪRỤ TEISEI}

\begin{abstract}
ES teisè tiesiogiai ir netiesiogiai daro ịtakq šaliu nariu teisinèms sistemoms, ji taip pat taikoma ir jüru reikalams. Nors Lietuvos politinis ir ekonominis demesys labiau orientuotas $i$ didžiausius miestus - Vilniu ir Kauna, jürininkystès klausimai (nuo žvejybos iki transporto, turizmo iki energetikos) yra (ar gali tapti) svarbiais Lietuvos ekonominio ir politinio gyvenimo aspektais. Šiame tekste aptarta, kaip ES darbas gali daryti itaka vidaus jüru teisei. Tai parodyta nagrinejant ES ir valstybiu nariu saveika su pasaulinemis tarptautinemis sutartimis. Tarp daugelio rüšiu tarptautiniu sutarčiu, susijusiu su jüru reikalais, akademinès bendruomenès dažnai nepaiso atsakomybès konvencijų, nors jos labai svarbios jūru sektoriaus įmonèms, taip pat ir toms, kurios sqeveikauja su jüru dalyviais, pavyzdžiui, pakrančiu gyventojais, kruiziniu laivu arba keltu keleiviais. Naudojant pavyzdi, kaip ES igyvendina Atènu konvencija, kurioje reglamentuojama atsakomybè už laivu keleiviu patirta žala, šio teksto tikslas parodyti ne tik tam tikra potenciala, bet ir komplikacijas, kuriu gali kilti ES isitraukaint i teisine sriti, kuri jau dešimtmečius iki ES isteigimo buvo reglamentuota tarptautinèmis sutartimis.
\end{abstract}

\section{REIKŠMINIAI ŽODŽIAI}

Laivyba, teise, ES, gabenimas, transportas. 